\title{
IMPLEMENTASI HUKUM WARIS MINANGKABAU PADA MINANG PERANTAU \\ (Studi pada Ikatan Keluarga Minang Kota Depok)
}

\author{
Nurul Febrianti \\ Universitas Esa Unggul \\ nurul.febrianti@esaunggul.ac.id
}

\begin{abstract}
This study aims to obtain empirical information about the implementation of Minangkabau inheritance law towards Minang settled foreigner in Minang Family Association (IKM) Depok City. This study uses quantitative methods and extension of existing data, interviews, and documentation. Based on research results show the community of settled foreigner in IKM Depok city over low treasures or livelihoods vary in the practice of inheritance law. The heirs in Minangkabau inheritance law in the livelihoods of this study are four groups. First, the heirs who use Islamic law, which women get half of men. Secondly, the heirs are equally distributed inheritance rights of each child. Third, women get more than men. Fourth, heirs for women only, so all the livelihood of parents is delegated only for women. So it can be concluded that the implementation of Minangkabau inheritance law in Minang settled foreigner in IKM Depok City vary. This difference occurs because the background of the pattern of life and mindset within each family. Patterns of life and mindset that make a person or family apply inheritance law according to customary law, religious law, or positive law.
\end{abstract}

Keywords: inheritance law, Minangkabau inheritance law, Minang settled foreigner

\begin{abstract}
ABSTRAK
Penelitian ini bertujuan untuk memperoleh informasi empiris mengenai implementasi hukum waris Minangkabu pada Minang perantau di Ikatan Keluarga Minang (IKM) Kota Depok. Penelitian ini menggunakan metode kuantitatif dan pengumpulan data dilakukan dengan observasi, wawancara, dan dokumentasi. Berdasarkan hasil penelitian menunjukkan masyarakat Minang perantau di IKM Kota Depok pada harta pusaka rendah atau mata pencaharian berbeda-beda dalam melaksanakan hukum waris. Ahli waris dalam hukum waris Minangkabau pada mata pencaharian dalam penelitian ini terdapat empat kelompok. Pertama, ahli waris yang menggunakan hukum Islam, yakni perempuan mendapatkan setengah dari laki-laki. Kedua, ahli waris dibagi sama rata hak warisnya setiap anak. Ketiga, anak perempuan mendapatkan lebih banyak daripada anak laki-laki. Keempat, ahli waris hanya pada anak perempuan saja, jadi seluruh harta pencaharian orang tuanya dilimpahkan ke anak perempuan saja. Maka dapat disimpulkan bahwa imlementasi hukum waris Minangkabau pada Minang perantau di IKM Kota Depok berbedabeda. Perbedaan ini terjadi karena latar belakang dari pola hidup dan pola pikir di dalam setiap keluarga. Pola hidup dan pola pikir yang membuat seseorang atau keluarga menerapkan hukum waris sesuai dengan hukum adat, hukum agama, atau hukum positif.
\end{abstract}

Kata kunci: hukum waris, hukum waris Minangkabau, Minang perantau 


\section{PENDAHULUAN}

Di Indonesia terdapat berbagai suku bangsa, antara lain: Batak, Jawa, Sunda, Minangkabau, Bugis, Madura, Ambon, Betawi, dan sebagainya. Setiap suku bangsa memiliki adat istiadat maupun aturan masing-masing yang pasti dimiliki secara turun-temurun. Aturan ataupun adat istiadat tersebut mengenai perkawinan, perceraian maupun masalah waris. Yaswirman mengemukakan hukum waris di Indonesia dikenal tiga macam, yaitu: (1) hukum waris barat yang terdapat dalam kitab undang-undang hukum perdata; (2) hukum waris Islam yang merupakan ketentuan-ketentuan waris yang berasal dari Al-Qur'an dan Hadist; (3) hukum waris adat, setiap suku bangsa di Indonesia memiliki aturan adat yang mengatur tentang pembagian waris di dalam lingkungan internal masing-masing suku. Hukum waris adalah ketentuanketentuan yang mengatur kekayaan seseorang setelah pemiliknya meninggal dunia. Hukum waris juga dapat diartikan sebagai hukum yang mengatur harta kekayaan lingkungan keluarga karena wafatnya seseorang, maka akan ada pemindahan harta kekayaan yang ditinggalkan oleh yang mati. Purbacaraka dan Soekanto menerangkan dalam hukum adat waris mengenal adanya tiga sistem kewarisan, yakni: (1) sistem kewarisan individual yang merupakan sistem kewarisan bagi para ahli waris yang mewaris secara perseorangan harta peninggalan yang dapat dibagi-bagikan pemiliknya secara individual kepada (para) ahli waris; (2) sistem kewarisan kolektif, para ahli waris secara kolektif (bersama) mewarisi harta peninggalan yang tidak dapat dibagi pemiliknya kepada masing-masing ahli waris. (3) sistem kewarisn mayorat: a) mayorat laki-laki apabila anak laki-laki tertua pada saat pewaris meninggal atau anak laki-laki sulung merupakan ahli waris tunggal, b) mayorat perempuan apabila anak perempuan tertua pada saat pewaris meninggal adalah ahli waris tunggal.

Sistem kewarisan kolektif adalah sistem yang dianut oleh masyarakat Minangkabau. Dalam sistem ini warisan yang dibagikan biasanya berupa benda atau tanah yang dapat digarap sebagai lahan pertanian. Mereka bersama-sama menggarap tanah dan menikmati hasilnya.

Minangkabau ialah salah satu adat yang berasal dari Indonesia yang menganut sistem Matrilineal. Segala sesuatunya mengenai hukum adat, sistem kekerabatan di Minangkabau menggunakan sistem matrilineal. Matrilineal dapat diartikan sebagai struktur masyarakat yang diatur menurut garis keturunan ibu, yang kabalikan dari sistem patrilineal yang kebanyakan digunakan suku bangsa lain di Indonesia. Menurut Amir M.S (2006: 9) dalam sistem kekerabatan matrilineal terdapat 3 unsur yang paling dominan yaitu:

1. Garis keturunan menurut garis ibu.

2. Perkawinan harus dengan kelompok lain, di luar kelompok sendiri yang sekarang dikenal dengan istilah eksogami matrilineal.

3. Ibu memegang peran setral pendidikan, pengamanan kekayaan, dan kesejahteraan keluarga.

Dari ketiga unsur di atas, terlihat jelas bahwa sistem pewarisan harta sangat berkaitan dengan erat dengan sistem matrilineal yang diatur dalam masyarakat adat Minangkabau. 
Dalam Minangkabau segala sesuatunya diatur menurut hukum Ibu, seperti kekerabatan, keluarga, perceraian, hinhha pembagian waris diatur berdasarkan hukum ibu yang dilihat garis turunan menurut Ibu.

Sesuai dengan tertib menurut hukum ibu, maka ahli waris menurut hukum adat Minangkabau ditarik dari garis ibu. Ahli waris yang dimaksud apabila telah ada harta peninggalan yang ditinggalkan seseorang yang telah meninggal dunia atau disebut pewaris.

Dalam adat Minangkabau, harta peningglana atau warisan dapat berupa harta pusaka tinggi dan harta pusaka rendah (harta mata pencaharian). Menurut Yaswirman (2011: 154) harta pusaka tinggi ialah harta pusaka yang ahli warisnya yakni anggota-anggota keluarga yang dilihat dari garis ibu dan tentunya perempuan. Namun, sedangkana pusaka rendah adalah warisan yang ditinggalkan oleh seseorang pada generasi pertama. Ahli warisnya yang masih sedikit itulah yang menyebabkan statusnya masih dianggap rendah. Mereka dapat melakukan kesepakatan bersama untuk memanfaatkannya, baik dijual atau dibagi-bagi antara mereka, pusaka rendah berarti harta pencaharian suami istri dalam rumah tangga.

Depok merupakan kota kecil
yang tidak sedikit ditemukan perantau-peratau yang berasal dari Minangkabau. Perkumpulan perantau di Depok ini bernama Ikatan Keluarga Minangkabau Depok. Ikatan Keluarga Minang Depok berdiri pada tahun 1980 merupakan perkumpulan yang bertujuan untuk menghimpun dan merangkul perantau Minangkanau yang bermukim di Depok. Mereka mengadu nasib untuk berdagang dan menuntut ilmu. Seseorang yang lama dirantau pasti memiliki perubahan sosial dan kebudayaan. Menurut William F. Ogburn dalam Soekanto (2007: 264) menyatakan bahwa ada kondisikondisi sosial primer yang menyebabkan terjadinya perubahan. Misalnya kondisi ekonomis, teknologis, geografis, atau biologis menyebabkan terjadinya perubahanperubahan pada aspek-aspek kehidupan sosial. Perubahan inilah yang menjadi pergeseran terhadap masyarakat Minangkabau yang merantau.

Ditemukan hal yang menarik untuk dibahas dalam tulisan ini. Dari apa yang tertulis di dalam literatureliteratur yang Penulis baca mengenai adat Minangkabau, khususnya mengenai harta pewarisan ini, kenyataannya terdapat pergeseran yang terjadi dalam kehidupan nyata. Mamak kepala waris menurut Yaswirman (2011: 154) sering menggadaikan harta pusaka tinggi di luar ketentuan, kendati tidak boleh, ternyata hal ini berlangsung juga, bahkan ada yang menambah/mendalami terus harta gadainya sehingga tidak tertebus lagi.

Selanjutnya masih menurut Yaswirman (2011:150) dalam Minangkabau anak laki-laki berperan hanya sebagai pengawas terhadap harta waris yangada, sesuai dengan sistem kekerabatan masyarakat Minangkabau yang matrilineal, sehingga berhak mewaris adalah anak perempuan. Namun, pada kenyataannya saat ini di Minangkabau anak laki-laki sudah banyak menjadi ahli waris dari warisan yang ada.

Berdasarkan latar belakang tentang hukum waris Minangkabau dan masyarakat perantau 
Minangkabau di Depok yang didasari oleh pendapat William F. Ogburn, dapat dilihat masyarakat perantau akan berubah dalam sosial dan budayanya dalam penerapan hukum waris Minangkabau tersebut. Masyarakat perantau Minangkabau yang telah tinggal di Depok atau merantau ke kota akan mengalami perubahan dari semua aspek yang akan mempengaruhi penerapan hukum waris Minangkabau. Dalam penulisan ini penulis membatasi masalah hukum waris pada pusaka rendah atau harta mata pencaharian.

\section{METODOLOGI}

Penelitian ini bertujuan untuk mendeskripsikan, menggambarkan, dan mengungkapkan tentang implementasi hukum waris Minangkabau pada masyarakat Minangkabau perantau di Ikatan Keluarga Minang Kota Depok. Metode penelitian yang digunakan dalam penelitian ini adalah metode kualitatif. Penelitian kualitatif yakni mempelajari masalah-masalah dalam masyarakat, dan tata acara yang berlaku pada masyarakat, serta situasi-situasi tertentu, termasuk hubungan, kegiatan-kegiatan, pandangan-pandangan serta prosesproses yang sedang berlangsung dan pengaruh-pengaruh dari suatu fenomena.

Informan dalam penelitian ini adalah masyarakat Minangkabau yang menjadi perantau dan telah melakukan pembagian waris yang bertempat tinggal di Depok dan anggota dari IKM kota Depok berjumlah 5 informan. Sedangkan key informan dalam penelitian ini adalah tokoh masyarakat Minangkabau (Datuk) yang dianggap penting dan mengetahui secara mendalam terhadap hukum waris
Minangkabau pada masyarakat Minang perantau di IKM kota Depok terdiri dari 1 key informan.

Teknik pengumpulan data yang dilakukan pada penelitian ini yakni observasi, wawancara, dan dokumentasi. Observasi dilakukan oleh peneliti untuk mengumpulkan data yang sesuai dengan sifat penelitian karena mengadakan pengamatan secara langsung atau disebut penelitian terlibat, peneliti juga menjadi instrument atau alat dalam penelitian. Sehingga peneliti harus mencari data sendiri dengan tujuan langsung untuk mengamati dan mencari langsung ke beberapa informan yang telah ditentukan sebagai sumber data. Wawancara dalam penelitian ini temasuk dalam kategori in-depth interview, dimana dalam pelaksanaannya lebih bebas bila dibandingkan dengan wawancara terstruktur. Tujuan dari wawancara jenis ini adalah untuk menemukan permasalahan secara lebih terbuka, di mana pihak yang diwawancarai diminta pendapat dan ide-idenya. Dalam melakukan wawancara, penulis perlu mendengarkan secara teliti dan menatat apa yang dikemukakan oleh informan. Selanjutnya dalam studi dokumentasi dapat dikumpulkan dokumen yang berbentuk tulisan (arsip-arsip, bukubuku tentang pendapat, teori, dalil atau hukum-hukum, catatan, transkrip, buku, surat kabar, majalah, dsb), dokumen yang berbentuk gambar maupun elektronik.

Teknik kalibarasi keabsahan data dengan menggunakan member check, audit trial, trianggulasi, dan expert opinion. Selanjutnya dalam teknik analisis data menggunakan model interaktif Miles dan Huberman yaitu: reduksi data, penyajian data, 
dan penarikan kesimpulan dan verifikasi.

\section{KAJIAN PUSTAKA}

\section{A. Implementasi Hukum Waris}

Implementasi mempunyai dua pengertian dikutip dari KBBI (1) perlengkapan dengan perkakas, istilah (2) pelaksanaan. Umumnya istilah implementasi diartikan sebagai pelaksanaan sesuatu yang telah ditentukan sebelumnya. Implementasi juga dapat diartikan sebagai penerapan suatu hal. Penerapan dalam KBBI dapat diartikan pemasangan atau pengenaan atau juga perilah mempraktekan. Berdasarkan KBBI dapat diartikan implementasi adalah suatu kegiatan yang dilakukan oleh seseorang dengan usaha agar mencapai suatu tujuan.

Implementasi dalam hukum waris mengandung arti bahwa seseorang menerapkan suatu hukum yakni hukum waris dengan cara menyerahkan harta yang dimiliki kepada ahli waris. Penerapan waris di sini harus dilandasi dengan hukum, baik dengan hukum Islam, hukum nasional, ataupun hukum adat yang berada di Indonesia.

Hukum adalah peraturanperaturan atau ketentaun-ketentuan yang harus ditaati dan apabila melanggar akan mendapatkan sanksi. Menurut Djamali (2007: 147) hukum waris dalam sistem hukum masuk dalam hukum perdata. Hukum perdata ialah ketentuan-ketentuan yang mengatur dan membatasi tingkah laku manusia dalam memenuhi kepentingan kebutuhannya.

Setiap orang semasa hidupnya memiliki harta benda yang telah ia kumpulkan selama ia bekerja, untuknya maupun untuk keluarganya.
Lalu apabila ia meninggal pastinya akan meniggalkan harta benda yang ia dapatkan semasa hidup. Harta benda itulah yang dinamakan warisan dan harta benda tersebut akan dipindah tangankan oleh pewaris ke orang lain yang dinamakan ahli waris.

Dalam kehidupan masyarakat di Indonesia dilatar belakangi dari suku, bangsa, agama yang berbedabeda. Perbedaan ini yang membuat perbedaan antara suku satu dengan yang lain, atau agama satu dengan agama yang lain dalam pembagian waris.

Waris berasal dari Bahasa Arab. Waris artinya "yang ditinggal" atau "yang kekal". Makna dari "yang ditinggal" adalah harta, benda dan hutang. Sedengakan makna dari "yang kekal" maksudnya bendabenda yang kekal atau tidak bernyawa.

Waris ialah ketentuanketentuan tentang yang ditnggal oleh seseorang yang telah mati. Dalam Nasution (2011: 127) ketentuanketentuan tersebut berupa ketentuanketentuan mengenai:

1) Macam-macam hak dari pihak/orang lain yang masih melekat pada peninggalan simati.

2) Orang-orang yang menjadi ahli waris, urutan ahli waris serta perolehan masing-masing dari para ahli waris.

3) Cara menyelesaikan warisan (harta dan hak), yaitu peraturanperaturan berhitung dalam membagi pusaka.

Dari ketentuan-ketentuan yang telah diatur oleh kompilasi Hukum Islam, kaum muslim mengacu pada ketentuan tersebut. Menurut Amir Syarifuddin dalam Mohammad Daud Ali (2009: 313), hukum kewarisan Islam adalah hukum yang mengatur segala sesuatu yang berkenaan 
dengan paralihan hak atau harta seseorang setelah ia meninggal dunia kepada alhi warisnya.

Selanjutnya Amir Syarifuddin dalam Mohammad Daud Ali (2009: 314) menambahkan dalam kompilasi hukum Islam terdapat asas-asas hukum kewarisan Islam yang dapat disalurkan dari Al-Qur'an dan AlHadist, yakni:

1) Asas ijbari, mengandung arti bahwa peralihan harta dari seseorang yang meninggal dunia kepada ahli warisnya berlaku dengan sendirinya menurut ketetapan Allah tanpa digantungkan kepada kehendak pewaris atau ahli warisnya.

2) Asas bilateral, bahwa seseorang menerima haka tau bagian warisan dari kedua belah pihak: dari kerabat keturunan laki-laki dan kerabat keturunan perempuan.

3) Asas individual, bahwa harta warisan dapat dibagi-bagi kepada ahli waris untuk dimiliki secara perseorangan.

4) Asas keadilan berimbang, dapat diartikan sebagai keseimbangan antara hak dan kewajiban, keseimbangan antara yang diperoleh dengan keperluan dan kegunaannya.

Asas-asas tersebut merupakan dasar dari hukum waris atau sebagai pedoman dalam pembagian waris dalam sebuah keluarga agar tidak terjadi perselisihan atau pertentangan.

Menurut Djamali (2007: 165) berbeda pengertian hukum waris Islam dengan hukum waris nasional. Hukum waris ialah ketentuanketentuan yang mengatur nasib kekayaan orang setelah pemiliknya meninggal dunia. Menurut Pasal 832 KUH Perdata menyatakan bahwa: "yang berhak untuk menjadi ahli waris ialah para keluarga sedarah baik sah maupun luar kawin dan suami atau istri uang hidup terlama. Kalau keluarga sedarah atau suami atau istri yang hidup terlama tidak ada, maka segala harta peninggalan itu menjadi milik negara dengan melunasi segala utang sekedar harta peninggalan mencukupi itu."

Hukum waris menurut Soepomo (2003: 83) yang diatur dalam Burgerlijk Wetboek mengenal hak tiap-tiap waris atas bagian tertentu dari harta peninggalan, selanjutnya Soepomo menambahkan (2003: 84) bahwa berbeda engan hukum adat waris memuat peraturanperaturan yang mengatur proses meneruskan serta mengalihkan barang-barang harta benda dan barang-barang yang tidak terwujud benda dari satu generasi manusia kepada turunannya.

Hukum adat menurut Van Vollenhoven dalam Abdoel Djamali mengandung makna bahwa hukum Indonesia dan kesusilaan masyarakat merupakan hukum adat. Adat tidak dapat dipisahkan dan hanya mungkin dibedakan dalam akibat-akibat hukumnya. Istilah "hukum adat" biasa digunakan "adat" saja. Adat diartikan sebagian masyarakat awam sebagai kebiasaan atau perilaku sehar-hari yang terdapat di lingkungan sehari-hari yang di dalamnya terdapat norma-norma.

Menurut Hadikusuma (2003: 9) hukum waris adat itu mempunyai corak dan sifat-sifat tersendiri yang khas Indonesia, yang berbeda dari hukum Islam maupun hukum barat. Sebab perbedaannya terletak dari latar belakang alam fikiran bangsa Indonesia yang berfalsafah Pancasila dengan masyarakat yang Bhinneka 
Tunggal Ika. Maksud dari kalimat di atas menerangkan bahwa hukum waris adat yang berada di Indonesia tidak lepas dari nilai-nilai Pancasila yang menggambarkan sifat dari manusia Indonesia yang bersifat tolong-menolong guna mewujudkan kerukunan, keselarasan dan kedamaian dalam hidup.

Dapat dilihat perbedaan antara hukum waris Kompilasi Hukum Islam, hukum waris nasional, dan hukum waris adat. Perbedaan signifikan terdapat pada ahli waris, yakni akan pindah tangankan ke siapakah warisan yang telah ditinggal oleh pewaris. Selain dari perbedaan hukum waris Islam, hukum waris nasional, dan hukum waris adat, karena di Indonesia beragam suku budayanya, maka setiap budaya di Indonesia tentu tidak sama adatistiadatnya. Misalnya di suku Batak yang menganut sistem patrilineal, yakni garis keturunan berasal dari Bapak, berbeda halnya dengan di suku Minangkabau yang menganut sistem matrilineal, yakni garis keturunan berasak dari Ibu, atau dengan Aceh yang menganut sistem kekeluargan bilateral. Berbeda sistem kekeluargaan tentu berbeda juga dengan hukum adat yang dianut masing-masing budaya. Tentu saja berbeda cara mengimplementasikan hukum waris adatnya masing-masing.

\section{B. Hukum Waris Minangkabau}

Hukum waris Minangkabau termasuk aturan yang terdapat dari hukum adat. Hukum waris Minangkabau sama dengan sistem kekerabatan Minangkabau, dimana garis keturunan darah ialah menurut garis Ibu. Kehidupan yang mengatur segala sesuatnya dalam adat harus menurut tertib hukum Ibu.
Menurut Julius (2007: 3) pusaka atau harta pusaka di Minangkabau adalah harta kekayaan yang berbentuk barang atau benda yang diterima atau diwarisi dari leluhur secara turun-temurun menurut garis ibu dan dimiliki secara bersamasama oleh satu suku atau kaum. Dalam pusaka ini suatu kaum meninggalkan, misalnya: swah, lading, tanah kuburan, rumah gadang, keris, dan pakaian kebesaran Penghulu. Selanjutnya menurut Yaswirman (2011: 150) secara umum ada empat cara memperoleh harta di Minangkabau, yakni:

1) Pusako (pusaka) berupa warisan yang diterima dari mamak oleh kemenakan.

2) Tambilang Basi (tembilang besi), yakni harta yang diperoleh dengan hasil usaha sendiri, seperti dengan menaruko sawah atau membuka hutan untuk perladangan.

3) Tambilang Ameh (tembilang emas), yakni dengan cara pembelian. Karena harta di Minangkabau tidak dapat dibeli, maka caranya dilakukan dengan memegang gadai (pagang gadai).

4) Hibah, yakni harta yang diperoleh sebagai pemberian.

Pada masyarakat Minangkabau harta pusaka dibagi menjadi dua jenis, yakni harta pusaka tinggi dan harta pusaka rendah atau harta mata pencaharian. Harta pusaka tinggi merupakan warisan turuntemurun yang dimiliki suatu kaum atau suku yang diberikan dari satu generasi ke generasi berikutnya dan dikarang untuk diperjual belikan. Sedangkan harta pusaka rendah merupakan warisan yang diberikan seseorang pada generasi pertamanya.

Menurut Amir M.S (2006: 96) harta pusaka rendah adalah segala 
harta hasil pencaharian dari bapak bersama ibu (orang tua kita) selama ikatan perkawinan, ditambah dengan pemberian mamak kepada kemenakanannya dari hasil pencaharian mamak itu sendiri. Harta pusaka rendah memiliki dua pengertian berbeda dari hukum adat Minangkabau dengan hukum faraidh. Sebelum Islam masuk ke ranah Minang, hukum adat Minangkabau mengatakan bahwa harta puskaa rendah diberikan kepada kemenakan. Berbeda hal dengan hukum faraidh yang mengatakan bahwa ahli waris ditentukan berdasarkan hukum waris Islam.

Dalam hal pewarisan tersenuat di atas adat Minangkabau sudah disepakati dan diputuskan dalam Musyawarah Besar Urang Nan Ampek Jinih seluruh Sumatera Barat pada tanggal 2-4 Mei 1953 di Bukittingi, dan diperkuat dalam Seminar Hukum Adat Minangkabau, tanggal 21-25 Juli 1968 di Padang yang isinya menetapkan sebagai berikut:

1) Harta Pusaka (Pusako Tinggi), di Minangkabau merupakan harta bedan hukum, diurusi dan diwakili oleh mamak kepala waris, dimana mamak kepala waris maupun kemenakannya bukanlah pemilik dari harta badan hukum itu.

2) Harta Pencaharian (Pusako Rendah), diwarisikan menurut hukum faraidh. Harta pencaharian adalah seperdua dari harta yang didapat selama dalam perkawinan ditambah dengan harta bawaan sendiri (milik pribadi, bukan milik kaum).

3) Seseorang dibenarkan berwasiat kepada kemenakan atau kepada yang lain, hanya sebanyak- banyaknya sampai sepertiga dari harta pencaharian itu.

Ahli waris disini adalah orang atau orang-orang yang berhak meneruskan peranan dalam pengurusan harta pusaka. Pengertian ini didasarkan pada asas kolektif dalam pemilikan dan pengolahan harta serta hubungan seorang pribadi dengan harta yang diusahakannya itu sebagai hak pakai. Menurut adat Minangkabau pemegang harta secara praktis adalah perempuan karena ditangannya terpusat kekerabatan matrilineal.

\section{Minang Perantau}

Minang atau Minangkabau adalah salah satu suku dana tau adatistiadat yang berasal dari Indonesia. Minangkabau memeliki pengikut atau masyarakat yang berada di daerah Sumatera Barat, Riau, dan Jambi. Masyarakat dalam Bahasa Inggris dipakai istilah society yang berasal dari kata Latin yakni socius, yang berarti "kawan". Istilah masyarakat sendiri berasal dari akar kata Arab syaraka yang berarti "ikut serta, berpartisipasi". Masyarakat adalah sekumpulan manusia yang saling bergaul, atau dengan istilah ilmiah saling berkaitan (Koentjaraningrat, 2002:143).

Perantau berasal dari kata dasar rantau, yang menurut KBBI adalah daerah atau negeri orang lain; wilayah di luar kampong halaman, Lalu merantau yakni berlayar mencari penghidupan di sepanjang pantai; pergi ke negeri orang untuk bekerja atau mencari pengalaman. Sedangkan perantau sendiri adalah orang yang pergi merantau. (KBBI: 645).

Minang perantau dapat diartikan masyarakat Minangkabau yang meninggalkan kampung halamannya ke tempat atau negeri 
orang untuk mencari pengalaman, penghasilan, ataupun ilmu. Merantau merupakan proses interaksi masyarakat Minangkabau dengan dunia luar. Kegiatan ini merupakan sebuah petualangan pengalaman dan geografis, dengan meninggalkan kampong halaman untuk mengadu nasib di negeri orang. Para perantau biasanya telah pergi merantau sejak usia belasan tahun, baik sebagai pedagang ataupun penuntut ilmu. Bagi sebagian besar masyarakat Minangkabau, merantau merupakan sebuah cara yang ideal untuk mencapai kematangan dan kesuksesan. Maka, dengan merantau tidak hanya harta kekayaan dan ilmu pengetahuan yang didapat, namun juga prestise dan kehormatan individu di tengah-tengah lingkungan adat.

Dari pencarian yang diperoleh, para perantau biasanya mengirimkan sebagian hasilnya ke kampong halaman untuk kemudian diinvestasikan dalam usaha keluarga, yakni dengan memperluas kepemilikan sawah, memegang kendali pengolahan lahan atau menjemput sawah-sawah yang tergadai. Uang dari para perantau biasanya juga dipergunakan untuk memperbaiki sarana-sarana nagari, seperti masjid, jalan, ataupun pematang sawah.

Menurut Mochtar Naim (1975: 8) meratau adalah sebagai proses pendewasaan diri. Merantau adalah gerbang inisiasi yang harus dilalui untuk jadi orang, dan dilakukan waktu berumur muda, rataa-rata mereka pergi merantau dengan modal dengkul. Bekal yang dibawa cukup hanya untuk "pelepas sesak", atau sekadar cukup untuk memulai dari bawah.
Kalimat di atas bermakna bahwa merantau adalah cara yang kongkrit untuk mengubah kehidupan seseorang. Merantau dilakukan tidak dengan mudah, melainkan harus berjunag keras agar tercapai keberhasilan. Oleh karena itu, merantau lebih dilihat dari proses kedewasaan diri yang hasilnya nanti akan dirasakan saat kembali ke kampong halaman nanti.

\section{HASIL DAN PEMBAHASAN}

\section{A. Hasil}

1. Pewaris

Pewaris adalah seseorang yang meninggakan sebuah warisan untuk diberikan kepada ahli warisnya. Pewaris dapat memilih untuk mewariskan atau pelaksanaan pembagian waris dengan cara ditentukan sebelum dia meninggal atau dapat dikatakan saat pewaris masih hidup, atau setelah ia meninggal. Pewaris yang meninggalkan waris setelah ia meninggal tanpe memberikan amanat dengan kata lain dia tidak menentukan pembagian warisan dengan ketentuan dia, melainkan kesepakatan keluarga pewaris. Maka, dalam hasil penelitian ini ditemukan dua golongan sebagai pewaris, yakni:

a) Pembagian harta saat pewaris masih hidup

Pembagian harta yang dilaksanakan saat pewaris masih hidup dapat dikelompokkan menjadi dua. Pertama, harta pusaka rendah tersebut dibagi pewaris untuk ahli waris yang ditentukan oleh pewaris, menjadi milik individu, contoh seorang ayah menentukan membagi warisan sama rata pada setiap anak, atau memilih anak mendapatkan lebih banyak dibandingkan 
anak lainnya. Kedua, harta pusaka rendah dibiarkan begitu saja tetap untuk sebagai milik keluarga ahli waris.

b) Pembagian harta setelah pewaris meninggal

Jika saat pewaris masih hidup telah menentukan bagian ahli warisnya masing-masing baik dengan cara kepemilikan perseorangan maupun kolektif keluarga, maka pada pewarisan harta setelah pewaris meninggal, kondisi harta sama sekali belum dibagi untuk ahli waris. Disamping itu, pewaris juga tidak memberikan penjelasan tertentu yang harus dilaksanakan oleh ahli waris berhubungan dengan harta yang ditinggalkan. Singkat kata, proses yang dilaksanakan harta pusaka rendah yang ditinggalkan pewaris sepenuhnya menjadi tanggung jawab para ahli waris. Selanjutnya, para ahli waris akan membuat kesepakatan akan dilakukan dengan cara apa harta yang ditinggalkan oleh pewaris. Kesepakatan yang telah disepakati harus mencapai mufakat, agar tidak terjadi sengketa atau perselisihan dalam pembagian harta tersebut.

\section{Ahli Waris}

Ahli waris menurut hukum waris adar Minangkaba untuk harta pusaka rendah sama halnya dengan hukum waris Islam atau faraidh. Menurut hukum haris Islam atau faraidh oembagian anak laki-laki dan perempuan berbeda. Bila dalam perbandingan laki-laki dua sedangkan perempuan satu. Artinya, perempuan mendapatkan setengah dari yang didapatkan laki-laki. Dalam penelitian ini, para ahli waris yang ditemukan berbeda-beda. Ada yang sama seperti hukum faraidh bahwa perempuan mendapatkan setengah dari yang didapatkan dari laki-laki, ada yang membaginya sama rata, ada yang menjadikan ahli waris perempuan mendapatkan lebih banyak dibanding laki-laki, dan yang terakhir ada yang hanya perempuan yang menjadi ahli waris.

a) Ahli waris sesuai hukum waris Islam

Ahli waris sesuai hukum Islam yang menyatakan bahwa laki-laki mendapatkan hak lebih banyak ketimbang perempuan. Perempuan mendapatkan setengah dari yang didapatkan laki-laki. Dalam penelitian ini terdapat satu yang melaksanakan hukum waris ini, ayah mereka telah mengamanatkan hal tersebut. Seperti yang dikatakan Oxong Darmawan, bahwa:

"ayah kami meminta bila saatnya telah tiba, rumah orang tua kami harus dibagi secara hukum Islam dengan adik perempuan kami hanya mendapatkan setengah dari yang saya dapatkan dan adik laki-laki saya dapatkan."

Dari yang dikatakan oleh responden, ini menunjukkan bawha ayah mereka melaksanakan hukum waris Minangkabau dalam harta pusaka rendah. Hal ini dikarenakan harta pusaka rendah dalam hukum waris Minangkabau adalah hukum waris Islam atau hukum Faraidh.

a) Ahli waris dengan pembagian harta sama rata

Dalam pembagian harta sama rata semua ahli waris mendapatkan hal sama rata dalam 
pembagian waris. Hal ini seperti yang dilakukan keluarga Nurrahma Alisa Saman, ayah mereka tidak pernah mengamanatkan atau memberi pesan untuk begaimana pembagian waris tersebut. Lalu, keluarga ini memutuskan untuk membaginya sama rata. Pernyataan Nurrahma Alisa Saman, seperti ini:

$\begin{array}{lr}\text { "kami sembilan } \\ \text { bersaudara, saya adalah } \\ \text { anak perempuan } & \text { satu- } \\ \text { satunya dan kami sepakat } \\ \text { untuk membagi harta } \\ \text { nantinya dengan sama } \\ \text { rata." }\end{array}$

Pembagian harta sama rata tidak membeda-bedakan posisi anak, apakah anak tersebut pertama, anak perempuan satusatunya, atau lain sebagainya. Hal ini yang membuat kedudukan anak dianggap sama dalam sebuah keluarga.

b) Ahli waris dengan pembagian harta anak perempuan lebih banyak

Pemberian harta pusaka rendah kepada anak perempuan lebih banyak dibandingkan dengan anak laki-laki disebabkan anak laki-laki dirasa mampu berdiri sendiri tanpa belas kasih dari orang tua. Seperti yang diterangkan oleh Ardian Hamdani, yakni:

"ayah kami mengamanatkan bahwa rumah yang dimiliki orang tua kamu harus ditempati oleh saudara perempuan saya. Rumah boleh dijual apabila mendapatkan persetujuan dari saudara perempuan saya, dan apabila dibagi saudara perempuan saya tersebut harus mendapatkan hak lebih banyak dibandingkan dengan saya dan kedua adik saya."

Jelas dalam pernyataan responden Ardian Hamdani bahwa ayah responden lebih menginginkan harta yang ia miliki dan cari selama hidupnya dapat diberikan lebih ke anak perempuannya lebih banyak dibandingkan anak laki-laki.

d) Ahli waris dengan pembagian harta anak perempuan saja

Kelompok terakhir ini harta yang dimiliki orang tua dalam harta pusaka rendah diberikan semua pada anak perempuan saja. Memberikan harta kepada anak perempuan saja dilatarbelakangi oleh alasan pribadi orang tua. Biasanya rasa kasih saying berlebihan kepada anak perempuan. Di Minangkabau, sepasang suami istri sangat mendambakan anak perempuan karena anak perempuan tersebut akan meneruskan darah Minang (menurunkan suku). Seperti yang diketahui bahwa garis keturunan Minangkabau adalah matrilineal.

Dalam penelitian ini, ditemukan dua responden yang pembagian harta diserahkan semua pada anak perempuan saja. Perbedaan terletak pada pewaris, salah satu diamanatkan oleh orang tua dan salah satu lagi diambil oleh kesepakatan bersama. Taufik Hidayat adalah responden yang ayahnya mengamanatkan untu harta mata pencaharian selama dia hidup harus diberikan kepada saudara perempuan responden. Taufik Hidayat dalam penjelasannya sebagai berikut: 
"ayah kami sangat Minang, beliau ingin seluruh harta yang dia miliki jatuh ke saudara perempuan saya. Saya tidak merasa keberatan, karena dari kecil saya dididik sebagai anak lakilaki yang harus dapat mandiri. Saya merasakan perempuan di Minang memang sangat dilindungi. Mungkin itu mengapa ayah saya memberikan hak warisnya kepada saudara perempuan saya."

Responden selanjutnya adalah Catri Helmi yang sepakat untuk membagi waris dengan menyerahkannya pada saudara perempuannya. Ayah mereka memiliki dua anak laki-laki dan dua anak perempuan, dan mereka bersaudara sepakat untuk menyerahkan ahli warisnya untuk saudara perempuannya saja. Berikut penjelasan yang diberikat oleh Catri Helmi:

"kami empat bersaudara, dua lakilaki dan dua perempuan. Ayah kami tidak meninggalkan pesan, begitupu ibu kami, jadi kami sepakat rumah yang orang tua kami tempati untuk saudara perempuan kami. Saya dan kakak laki-laki saya merasa tidak berhak atas rumah itu, biar saja saudara perempuan kami yang mengurus rumah itu dan biar mereka yang membaginya kelak."
Alasan lainnya adalah anak laki-laki di Minangkabau setalah menikah akan pergi ke rumah istrinya (menjadi sumando) atau memiliki rumah sendiri. Itulah sebabnya maka anak laki-laki tidak perlu diberikan harta pusaka rendah oleh orang tuanya.

\section{b) Pusaka}

Pusaka adalah harta yang diwariskan pewaris kepada ahli waris. Pusaka harta mata pencaharian atau harta pusaka rendah biasanya berupa rumah, tanah, barang berharga, barang bergerak, atapun uang. Dalam penelitian ini, banyak pewaris meninggalkan harta peninggalan berupa rumah dan ada juga yang meninggalkan sebidang tanah.

\section{B. Pembahasan}

Hukum waris Minangkabau dalam harta mata pencaharian atau harta pusaka rendah sebenarnya tidak berbeda dengan yang diterapkan dalam hukum waris Islam. Hal ini sebenarnya disebabkan karena sering terjadi perselisihan antara para ahli waris. Sebelum hukum waris Minangkabau dalam harta mata pencaharian diberlakukan sama dengan hukum waris Islam, katentuan yang berlaku berbeda dengan hukum waris Islam. Dahulu ahli waris dalam harta pusaka rendah adalah kemenakannya, namun sekarang berbeda setelah ada keputusan Musyawarah Besar di Padang berubah menjadi sesuai hukum waris Islam atau hukum faraidh.

Kebanyakan orang memahami pewaris hukum waris Islam atau faraidh tidak memahami bahwa sebenarnya hukum faraidh mengandung pengaturan porsi-porsi warisan yang jauh lebih rumit. Sebenarnya bukan hanya anak yang 
mendapatkan waris, ayah dan ibu pewaris juga mendapatkan waris sebagai ahli waris.

Berdasarkan hasil temuan penelitian, responden yang diambil dari IKM Depok mengimplementasikan hukum waris Minangkabau ternyata berbeda-beda. Pewaris memiliki hak penuh dalam mewariskan harta pencahariannya selama dia hidup. Namun, pewaris bisa saja tidak memberikan pesan atau amanat kepada ahli waris karena disebabkan sesuatu hal. Bisa saja karena memang tidak diberi waktu oleh Tuhan sehingga pewaris tidak meninggalkan amantat, atau saja karena ingin harta itu dibiarkan saja untuk ahli warisnya.

Bila pewaris tidak meninggalkan amanat atas hartanya, maka para ahli waris akan membuat kesepakatan bersama. Kesepakatan bersama itu akan menghasilkan ketentuan bagaimana porsian atau bagian dalam pembagian harta yang ditinggalkan ayahnya itu. Ahi waris yang dimaksud dalam hukum Islam yakni laki-laki mendapatkan dua dan perempuan satu, berarti perempuan mendapatkan setengah dari yang di dapatkan laki-laki.

Pergeseran terjadi apabila seorang pewaris tidak melakukan pembagian waris seperti yang diterangkan di atas. Terjadi banyak pergeseran yang terjadi dalam mengimplementasikan hukum waris Minangkabau dan hukum waris Islam. Saat pembagian waris yang diterima ahli waris menjadi sama rata, atau perempuan lebih banyak, dana tau juga harta diberikan penuh untuk anak perempuan saja. Ahli waris yang hanya diberikan kepada anak dan keturunan perempuan saja sebenarnya berlaku pada harta pusaka tinggi. Namun, pada harta pusaka rendah juga terjadi hal seperti ini. Hal ini dapat terjadi karena seorang ayah sangat menyayangi putrinya dan dari didikan orang tuanya. Orang awam yang tahu hukum waris Minang pasti akan langsung menerka bahwa ahli waris sepenuhnya adalah anak perempuan.

Waris yang dibagi sama rata membuat keluarga tidak repot untuk membaginya, karena terdengar adil bagi setiap pihak. Posisi anak sulung, bungsu, laki-laki satu-satunya, atau perempuan satu-satunys tidak mempengaruhi pembagian waris. Pembagian waris sama rata sangat kecil kemungkinan terjadinya perselisihan pembagian waris.

Pembagian waris perempuan lebih banyak atau hanya perempuan saja yang menjadi ahli waris tidak aneh dalam masyarakat Minangkabau. Sebagaimana diketahui dengan sistem kekerabatan yang matrilineal, membuat keluarga Minangkabau sangat menghormati, menghargai, dan melindungi perempuan. Seorang anak laki-laki Minang tidak merasa iri ataupun heran akan hal ini, mereka justru dituntut untuk menjadi laki-laki yang tangguh. Sejak kecil mereka sudah diperlakukan keras agar mandiri dan dapat menghidupi keluarganya. Anak remaja di Minangkabau saat sudah usia baligh mereka akan tidur di surau, dan ketika sudah merasa cukup umur, mereka akan pergi merantau untuk melanjutkan hidup.

Dengan demikian, tidak heran jika laki-laki Minang rela dan ikhlas apabila harta warisan yang dimiliki orang tuanya jatuh ke tangan saudara perempuan mereka. Mereka merasa tidak memiliki hak atas harta pencahariaan orang tuanya, yang berhak adalah saudara perempuannya tersebut. Kemandirian dan tanggung 
jawab laki-laki yang membuat mereka dapat bertahan diperantauan dan tetap berpegang teguh pada adat. Kelak, mereka juga akan mengajarkan hal yang sama kepada anak laki-laki mereka.

Berbeda apabila seorang lakilaki Minang yang tidak diperlakukan secara Minang oleh orang tuanya, bisa saja mereka tidak terima apabila kelak nanti orang tuanya akan memberikan harta yang dimiliki kepada anak perempuannya, karena dia merasa bahwa dia juga memiliki ha katas harta tersebut.

\section{KESIMPULAN}

\begin{tabular}{lccr}
\multicolumn{2}{c}{ Berdasarkan } & dari hasil \\
penelitian dan & pembahasan \\
sebelumnya, maka dapat ditarik
\end{tabular} beberapa kesimpulan. Pertama, hukum waris Minangkabau pada harta pusaka rendah atau harta mata pencaharian dalam mewariskan pusaka atau harta, sama dengan hukum waris Islam, karena telah diputuskan pada saat Musyawarah Besar di Padang.

Kedua, hukum waris Minangkabau sebelum ajaran Islam masuk, ahli warisnya adalah kemenakan (keponakan) pada harta mata pencaharian. Namun, setelah ajaran Islam masuk maka dalam harta mata pencaharian diberlakukan hukum waris sesuai dengan ajaran Islam, misal perempuan mendapatkan bagian setengah dari laki-laki.

Ketiga, dalam implementasi hukum waris Minangkabau di Ikatan Keluarga Minang tidak semua informan mengimplementasikan hukum waris Minangkabau tersebut. Masyarakat Minang perantau pada umumnya berbeda-beda dalam mengimplementasikan hukum waris, hal ini dikarenakan perbedaan pola hidup dan pola piker di setiap orang dan keluarga.

Keempat, pada pewaris ditemukan dua golongan pewaris, pertama, ada yang membagi atau mengamanahkan hartanyasebelum meninggal. Kedua, pewaris membagi hartanya setelah meninggal, dengan kata lain pewaris tidak mengamanatkan apapun pada ahli waris, dan akan berakhir dengan kesepakatan bersama keluarga atau para ahli waris.

Kelima, dalam implementasi hukum waris di IKM Depok pada ahli waris ditemukan berbeda-beda. Ditemukan empat golongan ahli waris. (1) ahli waris berdasarkan hukum Islam dengan pembagian perempuan mendapatkan setengah dari yang didapatkan laki-laki. (2) Ahli waris yang dibagikan dengan sama rat. (3) Ahli waris dengan pembagian perempuan mendapatkan hak lebih banyak, dan yang terakhir (4) adalah ahli waris yang dengan pembagian harta hanya untuk anak perempuan saja.

Keenam, pusaka atau harta warisan lebih dominan berbentuk rumah dan sebidang tanah. Pembagian harta berbentuk uang dilakukan apabila rumah dijual. Terakhir, tidak ditemukan perselisihan atau pertengkaran dalam melaksanakan hukum waris disetiap keluarga, karena sudah diamanatkan oleh orang tua dan juga kesepakatan bersama setiap anggota keluarga.

\section{DAFTAR PUSTAKA}

Daud Ali, Mohammad. (2009). Hukum Islam. Jakarta: PT. Raja Grafindo Persada.

Djamali, R. Abdoel. (2007). Pengantar Hukum Indonesia. Jakarta: PT. Raja Grafindo Persada. 
Julius. (2007). Membangkik Batang Tarandam Adat Minangkabau. Bandung: Citra Umbara.

Koentjaraningrat. (2002). Pengantar Ilmu Antropologi. Jakarta: Rineka Cipta.

MS, Amir. (2006). Adat Minangkabau Pola dan Tujuan Hidup Orang Minang. Jakarta: PT. Mutiara Sumber Widya.

Naim, Mochtar. (1975). Perantauan Masyarakat dan Masalah Kewirausahaan. Essai

Nasution, Yusriah. (2011). Hukum Islam. Jakarta: Laboraturium Sosial Politik Press.

Nazir, Moh. (1998). Metode Penelitian. Jakarta: Ghalia Indonesia.

Soekanto, Soerjono. (2007). Sosiologi Suatu Pengantar. Jakarta: PT. Raja Grafindo Persada.

Soepomo. (2003). Bab-bab Tentang Hukum Adat. Jakarta: Pradnya Paramita.

Sugiyono. (2008). Metode Penelitian Pendidikan. Jakarta: Alfabeta.

Yaswirman. (2011). Hukum Keluarga. Jakarta: PT. Raja Grafindo Persada.

Kamus Besar Bahasa Indonesia. Jakarta: Gitemedia Press. 